\title{
Photosynthetic Performance of Guaranazeiro Plants as Affected by Glyphosate Application
}

\author{
Bruna N. Leite ${ }^{1}$, Karla Gabrielle D. Pinto ${ }^{1}$, Victor Alexandre H. F. dos Santos ${ }^{2}$, Marciel J. Ferreira ${ }^{3}$ \\ \& Sônia Maria F. Albertino ${ }^{1}$ \\ ${ }^{1}$ Department of Plant and Animal Production, Federal University of Amazonas, Manaus, Amazonas, Brazil \\ ${ }^{2}$ Coordination of Environmental Dynamics, National Institute of Amazon Researches, Manaus, Amazonas, \\ Brazil \\ ${ }^{3}$ Department of Forest Sciences, Federal University of Amazonas, Manaus, Amazonas, Brazil \\ Correspondence: Bruna N. Leite, Department of Plant and Animal Production, Federal University of Amazonas, \\ Manaus, Brazil. Tel: 55-(92)-992-662-362. E-mail: brunanleite@hotmail.com
}

Received: March 3, 2020

doi:10.5539/jas.v12n10p287
Accepted: August 30, $2020 \quad$ Online Published: September 15, 2020

URL: https://doi.org/10.5539/jas.v12n10p287

\begin{abstract}
The unsuitable use of herbicides damages many cultures. In cases of high infestations and presence of aggressive weed species in guarana (Paullinia cupana) culture, glyphosate application is advisable, but its impact on guarana physiology is unknown. Therefore, leaf photosynthetic characteristics were measured with the aim of identifying if the photosynthetic performance of guaranazeiro plants is affected in response to glyphosate application. Three glyphosate doses (0 (control); 324 and $432 \mathrm{~g}$ a.i. $\mathrm{ha}^{-1}$ ) were applied to two guaranazeiro cultivars (BRS-Andirá and BRS-Maués) selected on the basis of productive performance. An analysis was made of the effects of these doses on characteristics that represent the photosynthetic process: gas exchange, maximum quantum efficiency of PSII, performance index and chlorophyll content. The application of glyphosate did not affect the short-term responses relative chlorophyll content (SPAD index) and light use (chlorophyll $a$ fluorescence). After $168 \mathrm{~h}$, there were changes only in gas exchange variables. The effects of glyphosate doses on gas exchange was different between guaranazeiro cultivars. The photosynthetic performance of the guaranazeiro seems to be tolerant to the effects of short-term of glyphosate application.
\end{abstract}

Keywords: herbicide, photosynthesis, fluorescence, chlorophyll, Paullinia cupana

\section{Introduction}

Guaranazeiro is a very important crop for Brazil, which is the only commercial producer of guarana. Production is mostly concentrated in the States of Bahia and Amazonas, and the produce is mostly absorbed by the beverage industry in these regions (Companhia Nacional de Abastecimento [CONAB], 2019). In addition to their energetic properties, guaranazeiro seeds have more than 80 pharmacological properties that are beneficial to human well-being. For this reason, they are interesting for the pharmaceutical industry (Marques, Ferreira, Paula, Kleinc, \& Mello, 2019). Over time, the culture has been undergoing a modernization process in its production system, as well as species improvement and phytosanitary management to increase production per hectare (Tricaudi, Piton, \& Pereira, 2016). Among phytosanitary factors, weed control has great relevance in the production of guarana. The research of Soares, Albertino, Souza, Santos, and Silva (2019) found that in areas without weed control, production may be reduced by up to $50 \%$. Although some studies have found evidence that the use of herbicides is efficient and cheap for weed control in guaranazeiro crops, there are no registered products in Brazil (Fontes \& Nascimento Filho, 2007). For guaranazeiro (Paullinia cupana) crops, glyphosate is recommended against high infestations and presence of aggressive weed species, as it is an efficient method for this purpose (Pereira, 2005).

Herbicides are efficient in weed control; consequently, they increase crop productivity, but these products can affect the physiology and consequently the growth of non-target organisms through drift (Silva et al., 2016). The use of non-selective herbicides requires best practices to avoid unwanted deposition in the culture (Santos, Faria, Barros, Reis, \& Tuffi-Santos, 2016). The use of non-selective herbicides, such as glyphosate, is increasing and required in crops, because it is easy to use and has efficient action (Moraes \& Rossi, 2010). Glyphosate is one of 
the most widely used post-emerging herbicides in the world (Companhia de Tecnologia Ambiental do Estado de São Paulo [CETESB], 2018). When deposited in plants, it is absorbed quickly, translocated by the phloem to all plants and accumulated in growth areas. Its effect, however, depends on factors such as species, age, environmental conditions, application mode (Yamada \& Castro, 2007) and dose and frequency of application, which must be taken into account to avoid damage, even in tolerant cultivars (Albrecht et al., 2018). Glyphosate acts on the enzyme EPSPS synthase, directly affecting the synthesis of aromatic amino acids. However, indirect effects need to be considered. Stress caused by the herbicide glyphosate increases the production of reactive oxygen species, and these compounds affect photosynthetic processes (Gomes et al., 2014).

The improper use of glyphosate can alter numerous physiological functions of non-target plants directly and indirectly. Mechanisms such as gas exchange (Concenço et al., 2014), quantum performance functions of photosystem II and chlorophyll content (Correa \& Alves, 2010) can be affected. These changes have been confirmed by several research studies on glyphosate drift (Torres et al., 2012; Ferreira et al., 2015; Silva et al., 2016). The use of low doses of simulated glyphosate drift has been widely researched in order to provide further insights into their effects on the sensitivity of crops (Langaro, Nohatto, Perboni, Tarauco \& Agostinetto, 2014).

Although the use of the herbicide glyphosate occurs in big cultivation areas, there is limited knowledge about the effects of low doses of glyphosate on guaranazeiro. Thus, the objective of the present research was to investigate if the photosynthetic performance of guaranazeiro plants is affected in response to the application of glyphosate.

\section{Method}

\subsection{Plant Material and Growing Conditions}

The guaraná (P. cupana) seeds of BRS-Andirá and BRS-Maués cultivars were obtained from the Jayoro farm, located in the municipality of Presidente Figueiredo, $\left(01^{\circ} 96^{\prime} 04^{\prime \prime} \mathrm{S}\right.$ and $\left.60^{\circ} 14^{\prime} 37^{\prime \prime} \mathrm{W}\right) 120 \mathrm{~km}$ from the city of Manaus, in the State of Amazonas. One-year old seedlings were transferred to $3 \mathrm{~kg}$ pots, filled with substrate, whose composition and fertilization followed the method described by Pereira (2005). The experiment was conducted in a nursery, with irradiation reduced by $50 \%$ and intermittent mist fogging, controlled by evaporation equilibrium to avoid tissue dehydration. Seedling irrigation was performed on alternate days, with $50 \mathrm{ml}$ of water per pot, on average, based on field capacity. The seedlings that were treated and evaluated were selected and standardized to avoid interference.

\subsection{Treatments and Experimental Design}

The treatments consisted of the application of three doses of the herbicide glyphosate ( 0 (control); 324 and $432 \mathrm{~g}$ a.i. ha ${ }^{-1}$ ) directly on two cultivars of guaranazeiro (BRS-Maués and BRS-Andirá) and observation at three times after application $(0,48 \mathrm{~h}$ and $168 \mathrm{~h})$. The experiment was conducted in a completely randomized design with a $3 \mathrm{x}$ 2 factorial scheme (doses and cultivars) at three times. The experimental unit consisted of nine plants, with four replicates.

\subsection{Herbicide and Application Method}

We used a solution of glyphosate at 0 (control); 324 and $432 \mathrm{~g}$ a.i. $\mathrm{ha}^{-1}(0 ; 22.5$ and $30 \%$ of active ingredient Original Roundup, $360 \mathrm{~L}^{-1} \mathrm{~g}$ a.i. SC, Monsanto Company ${ }^{\circledR}$, USA) recommended for cleaning tha of tillage. The herbicide was applied using a backup sprayer with a 110.02 fan nozzle at $147.1 \mathrm{kPa}$ pressure (YAMAHO FT-16), in the morning. The group of seedlings from each treatment was placed in separate locations for the application of the herbicide, and for four hour's time, the seedlings did not receive nebulization and were kept separate. This measure was taken to avoid the possible influence between the doses as well as interference from nebulization in the effect of the herbicide. After this period, the seedlings returned to the countertops for evaluation.

\subsection{Guaranazeiro Cultivars}

The cultivars BRS-Maués and BRS-Andirá were selected for their productive and agronomic characteristics. They both have high yield per area and high caffeine content; also, they are tolerant to major diseases, and well adapted to the production areas (Nascimento Filho et al., 1999; Nascimento Filho, Atroch, Pereira, \& Araújo, 2007). The BRS-Maués cultivar is used in almost all planting areas in the State of Amazonas and BRS-Andirá is well accepted among producers.

\subsection{Leaf Photosynthesis-Related Measurements}

All experiments were evaluated at 0,48 and $168 \mathrm{~h}$ after herbicide application. The measurements were made during the morning (from 08:00 to 10:00 a.m.), on the second pair of fully expanded leaves with good sanitary aspect. 
The gas exchange variables measured were: net photosynthesis, transpiration, stomatal conductance and dark respiration. The measurements were performed with an infrared gas analyzer (LI-6400, LiCor, Licoln, NE, USA) adjusted to work with $400 \mu \mathrm{mol} \mathrm{s} \mathrm{s}^{-1}$ flux, and leaf chamber for $\mathrm{CO}_{2}$ concentration, temperature and $\mathrm{H}_{2} \mathrm{O}$ steam around $380 \pm 4 \mu \mathrm{mol} \mathrm{mol}{ }^{-1}, 31 \pm 1{ }^{\circ} \mathrm{C}$ and $21 \pm 1 \mathrm{mmol} \mathrm{mol}^{-1}$, respectively, with a saturating light pulse of $1000 \mu \mathrm{mol} \mathrm{m} \mathrm{m}^{-2} \mathrm{~s}^{-1}$, with specific measures, on one leaf per plant.

For the measurements of chlorophyll $a$ fluorescence, we submitted two leaves of each plant to dark adaptation for 30 minutes, using appropriate clips. Chlorophyll a fluorescence was recorded with a portable fluorometer (PEA, MK2-9600-Hansatech, Norfolk, UK), with $3000 \mu \mathrm{mol} \mathrm{m}^{-2} \mathrm{~s}^{-1}$ and wavelength $650 \mathrm{~nm}$ for $1 \mathrm{~s}$, with evaluation of maximum quantum efficiency of PSII $(F v / F m)$ and performance index (PI abs).

Chlorophyll content was estimated by the SPAD Index with a portable chlorophyll meter (model SPAD-502 Plus), on two leaves per plant.

\subsection{Statistical Analysis}

All data were submitted to the variance test and the Skott-knot test with $5 \%$ probability $(\mathrm{p}<0.05)$. The tests were performed for multiple comparison of means and submitted to the Shapiro-Wilk normality using Assistat software (Version 1.0, Brazil).

\section{Results}

The action of glyphosate doses over guaranazeiro cultivars did not have any significant effect on the chlorophyll content variable, whose averages ranged between 35 and 54 (Figure 1).
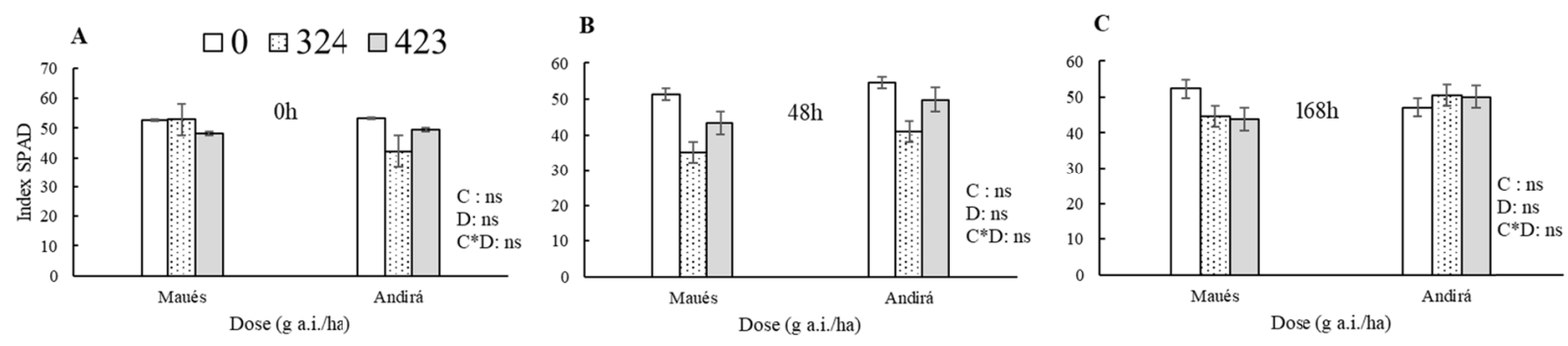

Figure 1. Chlorophyll content values in two guaranazeiro crops, submitted to three herbicide doses and its interaction, in three periods. The values without any letter are significantly equal at $\mathrm{P}<0.05$. C: cultivar; $\mathrm{D}$ : dose;

$\mathrm{C}^{*} \mathrm{D}$ : interaction between cultivar and dose

There was no interaction between the doses and the cultivars for the chlorophyll $a$ fluorescence variable. The average values of maximum quantum efficiency of PSII $(F v / F m)$ ranged between 0.760 and 0.830 , regardless of doses and evaluation times (Figures 2A, 2B and 2C). The average performance index (PI abs) values ranged between 5.44 and 12.16 (Figures 2D, 2E and 2F).

At $168 \mathrm{~h}$, performance of BRS-Maués was reduced as a result of the doses applied (Figure 2F). 

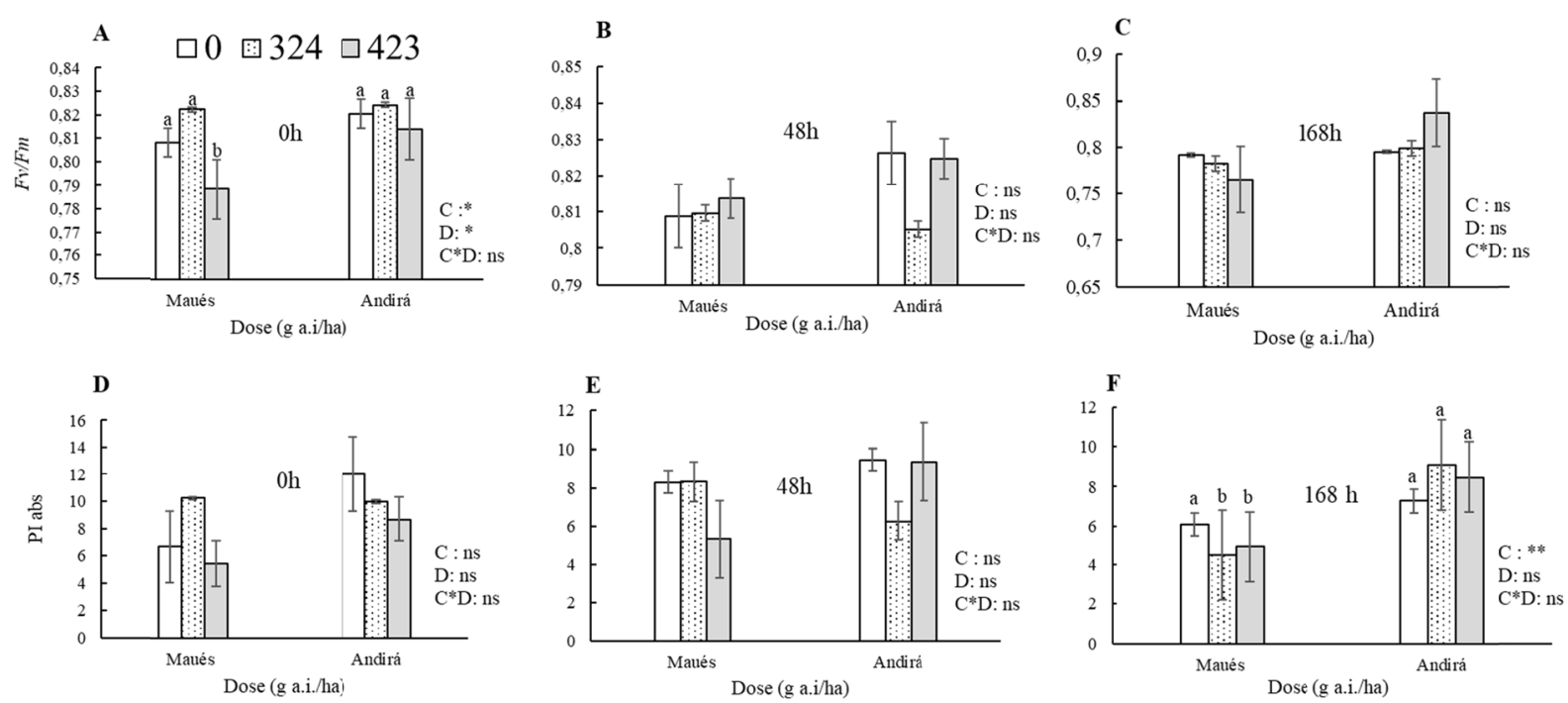

Figure 2. Maximum quantum efficiency of PSII $(F v / F m)$ and performance index (PI abs) in two guaranazeiro crops, submitted to three glyphosate doses and their interaction, in three periods. According to the Skott- Knott Test, C, cultivar; D dose; $C^{*} \mathrm{D}$, interaction between cultivar and dose; distinct letters are significantly different at $\mathrm{P}<0.05(*)$ or $<0.01(* *)$

Just $168 \mathrm{~h}$ after glyphosate application, there was an interaction between doses and cultivars. In this period, all of the investigated variables were changed. The dose of $423 \mathrm{~g}$ a.i. ha ${ }^{-1}$ did not affect gas exchanges of guaranazeiro cultivars in any period. However, the dose of $324 \mathrm{~g}$ a.i. ha ${ }^{-1}$ promoted variable increment for BRS-Maués and reduction forBRS-Andirá (Figures 3C; 3F; 3I and 3L). 

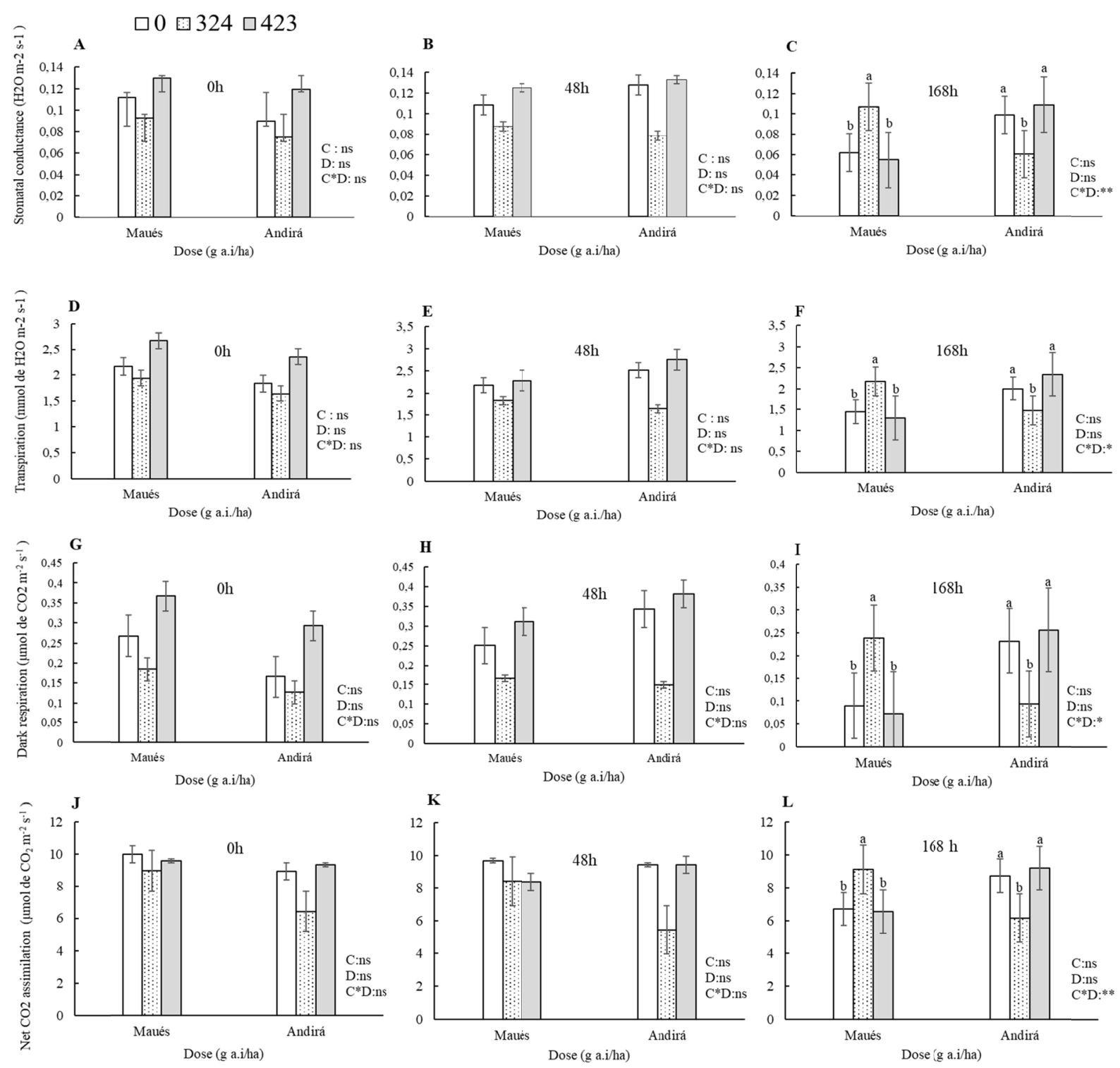

Figure 3. Values of stomatal conductance, transpiration, dark respiration and liquid assimilation of $\mathrm{CO}_{2}$ in two guaranazeiro cultivars submitted to three glyphosate doses and their interaction, in three periods. According to the Skott-Knott Test, C, cultivar; D dose; $C^{*} \mathrm{D}$, interaction between cultivar and dose; distinct letters are significantly different at $\mathrm{P}<0.05(*)$ or $<0.01(* *)$

\section{Discussion}

In this study, the low doses of glyphosate applied to guaranazeiro seedlings altered gas exchanges without affecting the parameters chlorophyll $a$ fluorescence and chlorophyll content. There was a difference between the doses applied and the crops. Herbicidal action depends on many factors, such as age, species, environmental conditions and doses applied (Torres et al., 2012). Olesen and Cedergreen (2010) found that the action of glyphosate on Hordeum vulgare affected gas exchanges, without affecting chlorophyll $a$ fluorescence; therefore, glyphosate-induced chemical stress breaks the interconnection between $\mathrm{CO}_{2}$ assimilation and electron transport, similarly to the effects of abiotic stresses, e.g., the cold. It is likely that the guaranazeiro seedlings also disassociated this interconnection, which indicates tolerance levels of the species to glyphosate, because the action of low glyphosate doses alters maximum quantum efficiency of PSII $\left(F_{\mathrm{v}} / F_{\mathrm{m}}\right)$ in susceptible species (Campos \& Ronchi, 2015).

Importantly, the crops of this research showed $F v / F m$ values that can be considered as normal according to the studies of Björkman and Demmig (1987), with 44 species, with diverse ways of life and growths; of Li, Niu, 
Jiang, and Liu (2004) with 99 species, and also of Gonçalves, Silva, Guimarães \& Bernardes (2010) with species from the Amazon region, in natural conditions. Another important variable that detects stress is PI abs, which is even more sensitive than the $F v / F m$ ratio (Christen, Schönmann, Jermini, Strasser, \& Défago, 2007). In our research, we found that glyphosate doses reduced PI abs only for the BRS-Maués cultivar.

The low doses of glyphosate may have unfavorable effects on gas exchanges of plant species. In a study with Arachis hypogea, even in low doses, glyphosate negatively affected gas exchanges for the species; owing to oxidative stress, there was an increase in antioxidant activity in the leaves, as a defense against glyphosate toxicity (Radwan \& Faye, 2016). In Glycine max cultivars, with higher doses than those established in this study, glyphosate severely affected the gas exchange of species, especially in the initial stages of crop establishment, caused by the reduction in the capture and use of light energy (Zobiole, Kremer, Oliveira Junior, \& Constantin, 2010). However, these processes were not affected in our research.

The change in gas exchange in plants is also subject to the characteristics of each genotype; a study with Eucalyptus $\times$ urograndis found that the changes caused by glyphosate were partially due to the differential accumulation of shikimic acid, rather than to the morphological, anatomical and defense characteristics of the species (Carvalho, Duke, \& Alves, 2018). However, a study with guaranazeiro showed that the differences in morphology and physiology of cultivars contribute to the photosynthetic performance of the species and their adaptability to adverse environmental conditions (Gonçalves et al., 2006). The morphological characteristics of each genotype of the same species alter the absorption of glyphosate by the plant, as in the study with Eucalyptus grandis, favoring the differential tolerance between the genotypes (Machado et al., 2009).

Despite the negative effects on gas exchange, low doses of glyphosate can also promote an increase. Carvalho, Alves, Silvano, and Prado (2012) found a stimulating effect of the application of glyphosate in young plants of Coffea arabica, although contradictory with the findings of other studies. The authors suggest that the processes behind this effect may be related to molecular characteristics, partial EPSPS inhibition or the use of $\mathrm{CO}_{2}$ however, they concluded that the growth phase of the species is crucial for this result. Vercampt et al. (2016) suggested that the energy generated through photosynthesis in young plants is directed, in part, to defense mechanisms, helping to overcome chemical stress. As mentioned above, this oxidative increase in plants can promote changes in gas exchange and may be related mainly to the young stage of the species. Low doses of glyphosate also stimulated gas exchange in plants of Hordeum vulgare, after seven days of treatment, owing to the increased efficiency of $\mathrm{CO}_{2}$ fixation. The authors concluded that the effect of glyphosate induces changes in the enzyme invertase, which may partially explain this stimulus (Cedergreen \& Olesen, 2010).

Nascentes et al. (2017), explain that low doses of glyphosate can promote hormetic effects in plants, depending on the study species, the dose of the herbicide and the stage of plant development. In studies with Saccharum officinarum and E. grandis, sublethal doses promoted biomass gain and plant growth, consequently increasing photosynthesis. In Phaseolus vulgaris plants, the hormonal effect of low doses of glyphosate was dependent on the cultivar and the dose; of the three evaluated cultivars, one suffered significant yield losses, while the other had increased yield in the highest underdoses (Silva, Arf, Gerlach, Kuryiama, \& Rodrigues, 2012).

There are countless processes that may account for the tolerance or intolerance of species to low doses of glyphosate, especially in terms of their effects on photosynthetic processes. Further research still needs to be carried out to clarify each of the mechanisms involved in the action of glyphosate, as the genetic characteristics of each species have their specificities, especially species from tropical environments, such as guaranazeiro. Another factor that needs to be taken into account is medium- and long-term responses, as they show other mechanisms and processes of adaptation to this stress.

\section{Conclusion}

The short-term responses relative to the photosynthetic performance of plants indicate the tolerance of cultivars Brs-Maués and Brs-Andirá to glyphosate application. However, we suggest conducting more comprehensive research with more doses for applicaton to guaranazeiro.

\section{Acknowledgements}

This study was financed in part by the Coordenação de Aperfeiçoamento de Pessoal de Nível Superior - Brasil (CAPES), and published with the financed support of the Programa de Apoio à Publicação de Artigos Científicos of the Fundação de Amparo à Pesquisa do Estado do Amazonas (PAPAC/FAPEAM). We would also like to thank Programa de Apoio à Manutenção de Equipamentos (PAMEQ/FAPEAM) and Agropecuária Jayoro. 


\section{References}

Albrecht, A., Albrecht, L., Barroso, A., Cesco, V. J., Krenchinski, F. H., Silva, A. F., ... Victoria Filho, R. (2018). Glyphosate Tolerant Soybean Response to Different Management Systems. Journal of Agricultural Science, 10, 204-216. https://doi.org/10.5539/jas.v10n1p204

Björkman, O., \& Demmig, B. (1987). Photon yield of $\mathrm{O}_{2}$ evolution and chlorophyll fluorescence characteristics at $77 \mathrm{~K}$ among vascular plants of diverse origins. Planta, 170, 489-504. https://doi.org/10.1007/ BF00402983

Campos, A. A. V., \& Ronchi, C. P. (2015). Interações entre tamanhos de vaso e doses de glifosato no controle de braquiária. Planta Daninha, 33, 727-738. https://doi.org/10.1590/S0100-83582015000400011

Carvalho, L. B., Alves, P. L. C. A., Silvano, B., \& Prado, R. (2012). Physiological dose-response of coffee (Coffea arabica L.) plants to glyphosate depends on growth stage. Chilean Journal of Agricultural Research, 72, 182-187. https://doi.org/10.4067/S0718-58392012000200003

Carvalho, L. B., Duke, S. O., \& Alves, P. L. C. A. (2018). Physiological responses of Eucalyptus $\times$ urograndis to glyphosate are dependent on the genotype. Scientia Forestalis, 46, 177-187. https://doi.org/10.18671/scifor. v46n118.04

Cedergreen, N., \& Olesen, C. F. (2010). Can Glyphosate Stimulate Photosynthesis? Pesticide Biochemistry and Physiology Journal, 96, 140-148. https://doi.org/10.1016/j.pestbp.2009.11.002

Christen, D., Schönmann, S., Jermini, M., Strasser, R. J., \& Défago, G. (2007). Characterization and early detection of grapevine (Vitis vinifera) stress responses to esca disease by in situ chlorophyll fluorescence and comparison with drought stress. Environmental and Experimental Botany, 60, 504-514. https://doi.org/10.1016/j.envexpbot.2007.02.003

Companhia de Tecnologia Ambiental do Estado de São Paulo. (2018). Glifosato. São Paulo, SP: Companhia de Tecnologia Ambiental do Estado de São Paulo.

Companhia Nacional de Abastecimento. (2019). Guaraná: Outubro de 2019. Brasilia, DF: Companhia Nacional de Abastecimento.

Ferreira, E. A., Matos, C. C., Barbosa, A. A., Silva, D. V., Santos, J. B., Pereira, G. A., ... Silva, C. T. (2015). Respostas fisiológicas da mandioca à aplicação de herbicidas. Revista Ciências Agrárias, 36, 645-656. https://doi.org/10.5433/1679-0359.2015v36n2p645

Fontes, J. R. A., \& Nascimento Filho, F. J. (2007). Controle de Plantas Daninhas em Guaranazais (Circular Técnica 29). Manaus, AM: Embrapa Amazônia Ocidental.

Galli, A. J. B., \& Montezuma, M. C. (2005). Glifosato: Alguns aspectos da utilização do herbicida glifosato na agricultura. Ed. ACADCOM.

Gomes, M., Smedbol, É., Chalifour, A., Hénault-Ethier, L., Labrecque, M., Lepage, L., ... Juneau, P. (2014). Alteration of plant physiology by glyphosate and its by-product aminomethylphosphonic acid: An overview. Journal of Experimental Botany, 65, 1-13. https://doi.org/10.1093/jxb/eru269

Gonçalves, J. F. C., Santos Júnior, U. M., Silva, J. F., Arruda, M. R., Bonates, L. C. M., \& Fernandes, A. V. (2006). Características fisiológicas e anatômicas de folhas de dois clones de guaraná. Pesquisa Agropecuária Brasileira, 41, 393-398. https://doi.org/10.1590/S0100-204X2006000300004

Gonçalves, J. F. C., Silva, C. E., Guimarães, D. G., \& Bernardes, R. S. (2010). Análise dos transientes da fluorescência da clorofila a de plantas jovens de Carapa guianensis e de Dipteryx odorata submetidas a dois ambientes de luz. Acta Amazonica, 40, 89-98. https://doi.org/10.1590/S0044-59672010000100012

Langaro, A. C., Nohatto, M. A., Perboni, L. T., Tarouco, C. P., \& Agostinetto, D. (2014). Alterações fisiológicas na cultura do tomateiro devido à deriva simulada de herbicidas. Revista Brasileira de Herbicidas, 13, 40-46. https://doi.org/10.7824/rbh.v13i1.282

Li, Y. G., Niu, S., Jiang, G., \& Liu, M. (2004). Traits of chlorophyll fluorescence in 99 plant species from the sparse-elm grassland in Hunshandak Sandland. Photosynthetica, 42, 243-249. https://oi.org/10.1023/ B:PHOT.0000040596.39460.6f

Machado, A. F. L., Ferreira, L. R., Santos, L. D. T., Santos, J. B., Ferreira, F. A., \& Viana, R. G. (2009). Absorção, translocação e exsudação radicular de glyphosate em clones de eucalipto: Clones. Planta Daninha, 27, 549-554. https://doi.org/10.1590/S0100-83582009000300016 
Marques, L. L. M., Ferreira, E. D. F., Paula, M. N., Kleinc, T., \& Mello, J. C. P. (2019). Paullinia cupana: A multipurpose plant-A review. Revista Brasileira de Farmacognosia, 29, 77-110. https://doi.org/10.1016/ j.bjp.2018.08.007

Moraes, P. V. D., \& Rossi, P. (2010). Comportamento ambiental do glifosato. Scientia Agraria Paranaensis, 9 , 22-35. https://doi.org/10.1818/sap.v9i3.5258

Nascentes, R. F., Carbonari, C. A., Simões, P. S., Brunelli, M. C., Velini, E. D., \& Duke, S. O. (2017). Low doses of glyphosate enhance growth, $\mathrm{CO}_{2}$ assimilation, stomatal conductance and transpiration in sugarcane and Eucalyptus. Peste Management Science, 74, 1197-1205. https://doi.org/10.1002/ps.4606

Nascimento Filho, F. J., Atroch, A. L., Cravo, M. S., Macêdo, J. L. V., Garcia, T. B., Costa Júnior, R. C., \& Ribeiro, J. R. C. (1999). Clones de guaranazeiro para o Estado do Amazonas (Comunicado Técnico 1). Manaus, AM: Embrapa Amazonia Ocidental.

Nascimento Filho, F. J., Atroch, A. L., Pereira, J. C. R., \& Araújo, J. C. A. (2007). Brs-Andirá: Cultivar de alta produção e resistente as principais doenças (Comunicado Técnico 55). Manaus, AM. Embrapa Amazonia Ocidental.

Olesen, C. F., \& Cedergreen, N. C. (2010). Glyphosate uncouples gas exchange and chlorophyll fluorescence. Pest Management Science, 66, 536-542. https://doi.org/10.1002/ps.1904

Pereira, J. C. R. (2005). Cultura do Guaranazeiro no Amazonas: Sistemas de Produção (4th ed.). Manaus: Embrapa Amazônia Ocidental.

Radwan, D. E. M., \& Faye, K. A. (2016). Photosynthesis, antioxidant status and gas-exchange are altered by glyphosate application in peanut leaves. Photosythetica, 54, 307-316. https://doi.org/10.1007/s11099-0160075-3

Silva, J. C., Arf, O., Gerlach, G. A. X., Kuryiama, C. S., \& Rodrigues, R. A. F. (2012). Efeito hormese de glyphosate em feijoeiro. Pesquisa Agropecuária Tropical, 42, 295-302. https://doi.org/10.1590/S19834063201200030000800008

Silva, L. Q., Araújo, A. C. F., Almeida, G. M., Crispim Filho, A. J., Costa, A. C., \& Jakelaitis, A. (2016). Modificações fisiológicas em folhas de pequi (Caryocar brasiliense) causadas pela aplicação de glyfosate. Revista Brasileira de Herbicidas, 15, 184-194. https://doi.org/10.7824/rbh.v15i2.472

Soares, D. O. P., Albertino, S. M. F., Souza, F. C. P., Santos, A. F., \& Silva, J. F. (2019). Period of weed interference in guarana crop. Revista Planta Daninha, 37, 1-4. https://doi.org/10.1590/s0100-83582 019370100070

Torres, L. G., Ferreira, E. A., Rocha, P. R. R., Faria, A. T., Gonçalves, V. A., Galon, L., ... Silva, A. A. (2012). Alterações nas características fisiológicas de cultivares de cana-de-açúcar submetida à aplicação de herbicidas. Revista Planta Daninha, 30, 581-587. https://doi.org/10.1590/S0100-83582012000300014

Tricaud, S., Pinton, F., \& Pereira, H. S. (2016). Saberes e práticas locais dos produtores de guaraná (Paullinia cupana Kunth var. sorbilis) do médio Amazonas: Duas organizações locais frente à inovação. Boletim do Museu Paraense Emílio Goeldi, 11, 33-53. https://doi.org/10.1590/1981.81222016000100004

Vercampt, H., Koleva, L., Vassilev, A., Horemans, N., Biermans, G., Vangronsvelda, J., \& Cuypers, A. (2016). The functional role of the photosynthetic apparatus in the recovery of Brassica napus plants from pre-emergent metazachlor exposure. Journal of Plant Physiology, 196-197, 99-105. https://doi.org/10.1016/ j.jplph. j2016.04.001

Yamada, T., \& Castro, P. R. C. (2007). Efeitos do glyfosate nas plantas: Implicações fisiológicas e agronômicas. International Plant Nutrition Institute. Encarte Técnico: Informações agronômicas.

Zobiole, L. H. S., Kremer, R. J., Oliveira Junior, R. S., \& Constantin, J. (2010). Glyphosate affects photosynthesis in first and second generation of glyphosate-resistant soybeans, Plant Soil, 336, 251-265. https://doi.org/10.1007/s11104-010-0474-3

\section{Copyrights}

Copyright for this article is retained by the author(s), with first publication rights granted to the journal.

This is an open-access article distributed under the terms and conditions of the Creative Commons Attribution license (http://creativecommons.org/licenses/by/4.0/). 